\title{
Are subpleural consolidations indicators for segmental pulmonary embolism in COVID-19?
}

Viviane Zotzmann ${ }^{1,2}$, Corinna N. Lang ${ }^{1,2}$, Fabian Bamberg ${ }^{3}$, Christoph Bode ${ }^{1,2}$ and Dawid L. Staudacher ${ }^{1,2^{*}}$

() 2020 The Author(s)

Dear Editor,

We congratulate Peng et al. [1] for their timely report on lung ultrasonography in COVID-19 patients. As reported earlier, pulmonary pathologies in the SARS$\mathrm{CoV}$-2-induced lung disease are detectable in early stages by computed tomography of the chest [2].Using lung ultrasonography with the 12-zone method,Peng et al. could identify several characteristics common to all COVID-19 patients. The point-of-care ultrasound offers several major advantages over the computed tomography concerning patient safety, avoidance of radiation, resource management and prevention of potential virus spreading as discussed by the authors. From our observations, we can confirm that signs discussed by the authors are present in our COVID-19 patients.

The findings described, however, are not exclusive for COVID-19. Wet lungs are seen in pulmonary edema of multiple causes. Even more important, the small subpleural triangular consolidations described as typical signs for COVID-19 are well known and described sonographic criteria for peripheral or segmental pulmonary embolisms with high sensitivity and specificity $(76.9 \%$ and $91.3 \%$, respectively) [3]. Interestingly, elevated d-dimers are frequently detected in COVID19 and are associated with adverse outcome [4], while the pathomechanism of the d-dimer elevation is not yet understood. As for SARS-CoV-1, there are in vitro data demonstrating induced hfgl 2 prothrombinase gene transcription, which promotes thrombosis. Reports on

\footnotetext{
*Correspondence: dawid.staudacher@universitaets-herzzentrum.de ${ }^{1}$ Department of Cardiology and Angiology I, Heart Center Freiburg University, Faculty of Medicine, University of Freiburg, Freiburg, Germany Full author information is available at the end of the article
}

empiric anticoagulation using heparin in patients with COVID-19 and elevated d-dimers suggest lower mortality [5], though pulmonary artery embolism was not investigated. Does COVID-19 mimic a peripheral or segmental pulmonary embolism or are subpleural triangular consolidations actually signs for pulmonary embolism?

In order to address this issue of immediate therapeutic relevance, we performed a bedside snapshot study and screened all SARS-CoV-2-positive patients on mechanical ventilation with elevated d-dimer levels for the presence of multiple subpleural consolidations. Three out of 10 patients met the inclusion criteria. Baseline characteristics were age 59-60 years, d-dimers $>35.2 \mathrm{mg} / \mathrm{l}$, pulmonary artery pressure estimated by transthoracic echocardiography 35-54 mmHg, no d-signs. None of the patients suffered from coagulopathy or clinical signs for thrombosis, and all were on prophylactic heparin therapy. Since likelihood for pulmonary embolism of these patients was considered medium to high, all patients underwent a chest contrasted computed tomography, which detected segmental pulmonary artery embolisms in all three patients.

Of course, we cannot rule out coincidental occurrence of pulmonary embolism. However, pulmonary artery embolism might be a specific complication of COVID19. We believe that the incidence of pulmonary embolism in COVID-19 patients has to be further investigated. In patients with elevated d-dimers and subpleural consolidations in lung ultrasonography, further diagnostic workup of a potential pulmonary embolism might be advised. Therefore, lung ultrasonography proposed by Peng et al. might be an addition rather than a replacement for computed tomography.

\section{Springer}




\section{Author details}

1 Department of Cardiology and Angiology I, Heart Center Freiburg University, Faculty of Medicine, University of Freiburg, Freiburg, Germany. ${ }^{2}$ Department of Medicine III (Interdisciplinary Medical Intensive Care), Medical Center, Faculty of Medicine, University of Freiburg, Freiburg, Germany. ${ }^{3}$ Department of Diagnostic and Interventional Radiology, Faculty of Medicine, University of Freiburg, Freiburg, Germany.

\section{Acknowledgements}

Open Access funding provided by Projekt DEAL.

\section{Compliance with Ethical Standards}

\section{Conflict of interest}

The authors declare that there is no conflict of interest.

\section{Open Access}

This article is licensed under a Creative Commons Attribution-NonCommercial 4.0 International License, which permits any non-commercial use, sharing, adaptation, distribution and reproduction in any medium or format, as long as you give appropriate credit to the original author(s) and the source, provide a link to the Creative Commons licence, and indicate if changes were made. The images or other third party material in this article are included in the article's Creative Commons licence, unless indicated otherwise in a credit line to the material. If material is not included in the article's Creative Commons licence and your intended use is not permitted by statutory regulation or exceeds the permitted use, you will need to obtain permission directly from the copyright holder.To view a copy of this licence, visit http://creativecommons.org/licen ses/by-nc/4.0/.

\section{Publisher's Note}

Springer Nature remains neutral with regard to jurisdictional claims in published maps and institutional affiliations.

Accepted: 6 April 2020

Published online: 23 April 2020

\section{References}

1. Peng Q-Y, Wang X-T, Zhang L-N, CCCUSG (2020) Findings of lung ultrasonography of novel corona virus pneumonia during the 2019-2020 epidemic. Intens Care Med. https://doi.org/10.1007/s00134-020-05996-6

2. AiT, Yang Z, Hou H et al (2019) Correlation of chest CT and RT-PCR testing in coronavirus disease 2019 (COVID-19) in China: a report of 1014 cases. Radiology. https://doi.org/10.1148/radiol.2020200642

3. Reißig A, Heyne J-P, Kroegel C (2004) Ancillary lung parenchymal findings at spiral CT scanning in pulmonary embolism. Relationship to chest sonography. Eur J Radiol 49(3):250-257. https://doi.org/10.1016/s0720 $-048 \times(03) 00141-4$

4. Huang C, Wang Y, Li X et al (2020) Clinical features of patients infected with 2019 novel coronavirus in Wuhan, China. Lancet Lond Engl 395(10223):497-506. https://doi.org/10.1016/s0140-6736(20)30183-5

5. Tang N, Bai H, Chen X, Gong J, Li D, Sun Z (2019) Anticoagulant treatment is associated with decreased mortality in severe coronavirus disease 2019 patients with coagulopathy. JThromb Haemost. https://doi.org/10.1111/ jth.14817 